\title{
Hypercalcaemia due to sarcoidosis corrects with bisphosphonate treatment
}

\author{
Charles J. Gibbs and Munro Peacock
}

MRC Mineral Metabolism Unit, The General Infirmary, Leeds LS1 3EX, UK.

\begin{abstract}
Summary: We report a case of sarcoid hypercalcaemia treated with the bisphosphonate, APD I(3amino-l-hydroxypropylidene)-1,1-bisphosphonate]. Investigations showed that the hypercalcaemia was associated with a high plasma 1,25 dihydroxy vitamin $D$ concentration. A low dietary intake of calcium partially corrected the hypercalcaemia but APD rapidly normalized plasma calcium without reducing the elevated 1,25 dihydroxy vitamin $D$ concentration. The case demonstrates that hypercalcaemia in sarcoidosis results from the effects of 1,25 dihydroxy vitamin $D$ on bone as well as on calcium absorption and that prolonged suppression of the effect on bone occurs with APD treatment.
\end{abstract}

\section{Introduction}

Sarcoid hypercalcaemia is considered to arise from calcium hyperabsorption and is due to excessive production of 1,25 dihydroxy vitamin $\mathrm{D}\left[1,25(\mathrm{OH})_{2} \mathrm{D}\right]$ by macrophages (Adams et al., 1983; Mason, 1985).

We report a case of sarcoid hypercalcaemia in whom the target effects of $1,25(\mathrm{OH})_{2} \mathrm{D}$ were mitigated by the bisphosphonate, APD [(3-amino-l-hydroxypropylidene)-1,1-bisphosphonate].

\section{Case report}

The patient, a Caucasian man, was diagnosed as having sarcoidosis on a chest radiograph at the age of 21 , confirmed by lung and liver biopsies. He remained asymptomatic without treatment until the age of 50 when he developed syncopal attacks due to complete heart block. A permanent pacemaker was implanted and prednisolone $10 \mathrm{mg} /$ day was given for 3 months. Asymptomatic hypercalcaemia was found at the age of 63. No treatment was given until he underwent investigations at the age of 65 which showed: haemoglobin $13.5 \mathrm{~g} / \mathrm{dl}$, ESR $52 \mathrm{~mm} /$ hour, plasma urea $12.2 \mathrm{mmol}$ and plasma creatinine $141 \mu \mathrm{mol} / \mathrm{l}$. Plasma alkaline phosphatase was $15 \mathrm{KAU} / 1$ with heat stability indicating a liver origin and $\gamma$-glutamyl transpeptidase was $73 \mathrm{IU} / 1$ (normal range 6-28). Serum angiotensinconverting enzyme (ACE) was $30 \mathrm{IU} / \mathrm{ml}$ (normal range $0-28$ ). A chest radiograph showed pulmonary fibrosis, but skeletal survey was normal. Gallium scan showed no areas of increased uptake in chest or

Correspondence: M. Peacock, M.B., F.R.C.P.

Accepted: 30 April 1986 abdomen. Plasma calcium was $3.22 \mathrm{mmol} / 1$ (normal range $2.26-2.60$ ) and plasma phosphate $1.09 \mathrm{mmol} / \mathrm{l}$ (normal range $0.8-1.3)$. Urinary calcium was $14 \mathrm{mmol} / 24$ hours (normal range 1-10) and after an overnight fast urinary calcium/creatinine ratio was 1.15 (molar) (normal <0.40) and hydroxyproline/ creatinine ratio 0.017 (molar) (normal $<0.015$ ). Plasma parathyroid hormone was $125 \mathrm{pg} / \mathrm{ml}$ (normal range 125-375), plasma 25 hydroxy vitamin D (25OHD) was $84.3 \mathrm{nmol} / 1$ (normal range 9-90 nmol/l) and $1,25(\mathrm{OH})_{2} \mathrm{D}$ was $346 \mathrm{pmol} / 1$ (normal range 75-165). Radiocalcium absorption was 0.78 (normal range 0.4-1.2) (Nordin, 1976).

He was treated consecutively with hydrocortisone, a low calcium diet and APD (Figure 1). An infusion of hydrocortisone $200 \mathrm{mg}$ over 24 hours resulted in a fall in plasma $1,25(\mathrm{OH})_{2} \mathrm{D}$ to $313 \mathrm{pmol} / \mathrm{l}$ and plasma calcium to $3.09 \mathrm{mmol} / 1$ and an increase in urinary calcium/creatinine ratio to 1.50 (molar). A low calcium diet $(5 \mathrm{mmol} / \mathrm{day})$ for 3 weeks resulted in partial correction of his elevated plasma calcium to $2.71 \mathrm{mmol} / 1$ and urinary calcium/creatinine ratio to $0.60 \mathrm{mmol} / 1$. Intravenous infusion of APD $5 \mathrm{mg} /$ day, however, resulted in a normal plasma and urine calcium and a fall in hydroxyproline/creatinine ratio to 0.006 within 3 days, despite a persistently high plasma $1,25(\mathrm{OH})_{2} \mathrm{D}$ concentration which remained unchanged without further treatment.

Calculation of the components of hypercalcaemia (Selby et al., 1984) showed that the hypercalcaemia was almost entirely due to increased throughput of calcium, with a small 'GFR' component due to renal impairment. The fall in plasma calcium on hydrocortisone was due to reduced tubular reabsorption of 
calcium, whereas the change on low calcium diet and APD was due to reduction in throughput.

\section{Discussion}

Investigations in our patient showed that the hypercalcaemia was mainly due to a high calcium throughput (Figure 1). Calcium absorption, however, was within the normal range although it was high relative to kidney function but low relative to the high plasma $1,25(\mathrm{OH})_{2} \mathrm{D}$ concentration.

Infusion of hydrocortisone reduced $1,25(\mathrm{OH})_{2} \mathrm{D}$ concentration only slightly and the fall in plasma calcium was due to a reduction in tubular reabsorption of calcium.

The low calcium diet reduced the plasma calcium concentration but not into the normal range, suggesting that the hypercalcaemia was not entirely due to hyperabsorption of calcium. Furthermore, this reduction occurred during a period in which there was a fall in plasma $250 \mathrm{HD}$ from 84 to $39 \mathrm{nmol} / \mathrm{l}$ and a consequent fall in plasma $1,25(\mathrm{OH})_{2} \mathrm{D}$ concentration, probably because of decreased ultraviolet radiation exposure.

In view of the adverse effects of hydrocortisone on bone mass and its minor effect on plasma $1,25(\mathrm{OH})_{2} \mathrm{D}$ concentration in this patient, APD, an inhibitor of bone resorption (Reitsma et al., 1980) was used. APD normalized the plasma calcium without reducing the plasma concentration of $1,25(\mathrm{OH})_{2} \mathrm{D}$ or ACE showing that the hypercalcaemia was due to the effect of $1,25(\mathrm{OH})_{2} \mathrm{D}$ on bone and that APD did not directly modify the activity of the granuloma. However,

\section{References}

ADAMS, J.S., SHARMA, O.P., GACAD, M.A. \& SINGER, F.R. (1983). Metabolism of 25 -hydroxy vitamin $D_{3}$ by cultured pulmonary alveolar macrophages in sarcoidosis. Journal of Clinical Investigation, 72, 1856.

MASON, R.S. (1985). Extra-renal production of $1,25(\mathrm{OH})_{2} \mathrm{D}_{3}$. Vitamin D: Chemical, Biochemical and Clinical Update. Proceedings of 6th Workshop on Vitamin D, Norman, A.W., Schaefer, K., Grigoleit, H.-G. \& Herrath, D.V. (eds). p. 23. Walter De Gruyter: London, New York.

NORDIN, B.E.C. (1976). Calcium, Phosphate and Magnesium

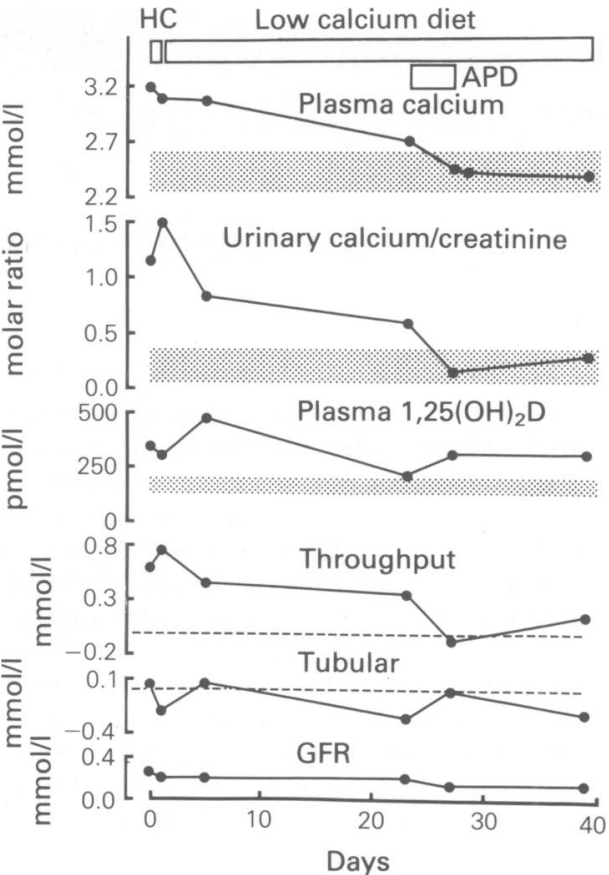

Figure 1 Biochemistry and components of hypercalcaemia during treatment with hydrocortisone (HC), low calcium diet and APD. The stippled areas represent normal ranges and the dotted lines indicate zero.

normocalcaemia persisted despite a rise in plasma $1,25(\mathrm{OH})_{2} \mathrm{D}$ indicating the prolonged effect of APD in suppressing the action of $1,25(\mathrm{OH})_{2} \mathrm{D}$ on bone resorption.

Metabolism. Churchill Livingstone: Edinburgh.

REITSMA, P.H., BIJVOET, O.L.M., VERLINDEN-OOMS, H. \& VAN DER WEE-PALS, L.J.A. (1980). Kinetic studies of bone and mineral metabolism during treatment with (3-amino-1hydroxy-propylidene)-1,1-biphosphonate (APD) in rats. Calcified Tissue International, 32, 145.

SELBY, P.L., PEACOCK, M. \& MARSHALL, D.H. (1984). Hypercalcaemia: management. British Journal of Hospital Medicine, 31(3), 186. 